\title{
PRODUCTION OF PROBIOTIC YOGHURT FORTIFIED WITH DATE SEEDS (phoenix dactylifera L.) POWDER AS PREBIOTIC AND NATURAL STABILIZER
}

\author{
WEDAD M. EL-KHOLY \\ Dairy Research Department, Food Technology Research Institute, ARC, Egypt.
}

(Manuscript received 31 October 2017)

\begin{abstract}
$T$ he present study aimed to evaluate the use of date seeds powder (DSP) as a natural prebiotic stabilizer in the manufacture of set yoghurt and their effect on some physicochemical, microbiological, rheological and sensory properties of this yoghurt during storage period at $4 \pm 1^{\circ} \mathrm{C}$. Probiotic set yoghurt was produced using common yoghurt starter culture and probiotic starter culture ABT-2. Titratable acidity showed a slight decrease as a result of increasing the percentage of DSP level. It was found that the water holding capacity of yoghurt samples ranged from $62.17 \%$ to $79.43 \%$ during storage period. The addition of DSP to probiotic set yoghurt stimulated the growth of probiotic bacteria. The total viable counts of $(S$. thermophilus ST-20Y, L. acidophilus LA-5 and B. bifidum BB-12) decreased slightly during the refrigerated storage, but remained at sufficient levels ( $>6 \log \mathrm{cfu} / \mathrm{g}$ ) for up to 14 days. The coliform and mould \& yeast counts were not detected in all samples. The use of DSP as a prebiotic and natural stabilizer at concentration of $0.5 \%$ in probiotic set yoghurt manufacture improved their sensory and rheological properties.
\end{abstract}

Key words: Date seeds powder (DSP), prebiotic stabilizer, probiotic set yoghurt.

\section{INTRODUCTION}

Yoghurt is a fermented milk product, which is produced by fermenting milk with bacterial cultures consisting of a mixture of Lactobacillus delbrueckii subsp. bulgaricus and Streptococcus thermophiles (Tamime \& Robinson, 1999) which are responsible for development of typical yoghurt flavour. Yoghurt may have two primary defects: variation in viscosity and/or syneresis. Processing, incubation and storage conditions have an effect on these changes. Dairy ingredients and stabilizers have sometimes been added to overcome such defects. Stabilizers are often added to the milk base to enhance or maintain the appropriate yoghurt properties including texture, mouth feel and appearance, viscosity /consistency and to prevent whey separation (Tamime \& Robinson, 1999).

The date palm (Phoenix dactylifera L.) is one of the major fruit trees in Egypt and many regions of the world. The fruit is composed of a fleshy pericarp and seed (pits) which constitute approximately $10-15 \%$ of the total fruit weight (Almana \& Mahmoud, 
1994). Date pits could be used as an excellent source of functional food component because they contain a balance of fats, proteins, minerals and carbohydrates. Chemical composition of date pits showed high amount of fibre ( 75 to $80 \%$ ), fat (10 to $13 \%$ ), proteins (5 to $6 \%$ ) and ash (Al-Farsi et al. 2007). Other studies have also revealed much higher amounts of phenolic content and antioxidant in date pits as compared to the corresponding flesh (Al-Farsi et al. 2007). Date pits are a major waste product of the date industry that could offer potentially valuable material for the production of useful food ingredients. This waste product of date processing industries could be regarded as an excellent source of food ingredients with interesting technological functionality that could also be used in food as an important source of dietary fiber without any negative impact on sensory quality of end-products if the pits are properly milled (Almana \& Mahmoud, 1994). The polysaccharide content is often expressed in terms of the fiber content, and is divided into crude fiber, neutral detergent fiber (NDF) and acid detergent fiber (ADF). Hamada et al. (2002) indicated the presence of high content of lignin and resistant starch in date pits.

Resistant starch is a type of starch that is resistant to digestion. Resistant starches are considered polysaccharides in which several monosaccharides, in this case is glucose. Resistant starch is used in food products due to its physicochemical properties including swelling, increased viscosity, gel formation, and water-binding capacity. Due to the resistance to digestive enzymes, resistant starch can be used as a dietary fiber. There is also an evidence that resistant starch may have prebiotic activity due to the resistance to digestion and subsequent fermentation, resulting in an increase in bowel health. It stimulates the growth of probiotic bacteria and improves culture viability (Ha \& Zemel, 2003).

The present study aimed to evaluate the use of date seeds powder (DSP) at different ratio as a prebiotics and natural stabilizer in set yoghurt manufacture and its effect on some physicochemical, microbiological, rheological and sensory properties of probiotic set yoghurt during storage period at $4 \pm 1^{\circ} \mathrm{C}$.

\section{MATERIALS AND METHODS}

\section{Materials:}

Fresh liquid skimmed cow milk (0.16\% titratable acidity as lactic acid, $\mathrm{pH}$ $6.52,0.44 \%$ fat, protein $2.65 \%$ and $9 \%$ SNF) was used in the manufacture of probiotic set yoghurt and was obtained from dairy farm of Agriculture College, Alexandria University, Egypt. Skimmed milk powder "Miro" (95\% T.S., 1.2\% fat and $32 \%$ protein) was obtained from Alexandria local market. Dried date fruits (Phoenix dactylifera L.) of Bent-Aisha dates were purchased from the Pomology Department 
Faculty of Agriculture, Alexandria University, Egypt. 2, 2-diphenyl-1-picrylhydrazyl (DPPH) and Butylated Hydroxy Toluene (BHT) were purchased from Sigma-Aldrich, Germany. Other chemicals and reagents used in the present study were of analytical grade and purchased from El-Gomhouria Co. for trading chemical and medical Appliances, Alexandria, Egypt. A commercial classic yoghurt starter containing $S$. thermophilus and $L$. bulgaricus strains (1:1) and probiotic starter culture ABT-2 which consists of S. thermophilus ST-20Y, L. acidophilus LA-5 and B. bifidum BB-12 were obtained from Chr. Hansens laboratories, Denmark) were used. Starter cultures were freeze-dried direct-to-vat set (DVS) form and stored at $-18^{\circ} \mathrm{C}$ until used. ABT-2 were added to the milk after the preliminary incubation at $37 \pm 1^{\circ} \mathrm{C}$ for $18 \mathrm{~h}$.

\section{Methods}

\section{Preparation of defatted date seeds powder (DSP):}

About $100 \mathrm{~g}$ of seeds were separated from the date fruits soaked in water, washed several times to remove any adhering date flesh and then air dried for $24 \mathrm{~h}$ at room temperature. Dried seeds were milled in a heavy-duty grinder, and then sieved using 1 to $2 \mathrm{~mm}$ mesh sieve to obtain a homogeneous fraction and the obtained powder was preserved at $-20^{\circ} \mathrm{C}$ until analysis. Oil was extracted from the obtained powder by a Soxhlet extraction apparatus using $\mathrm{n}$-hexane as a solvent for $16 \mathrm{~h}$. The DSP was kept in plastic container at $-20^{\circ} \mathrm{C}$ until further use.

\section{Manufacture of probiotic set yoghurt}

The total solid content of milk was standardized to $12 \%$ by adding $30 \mathrm{~g}$ skimmed milk powder and divided into four equal batches. One batch was kept without stabilizer as a control (C). To the other three batch $(0.1 \%, 0.3 \%$ and $0.5 \%)$ of DSP were added $\left(T_{1}, T_{2}\right.$ and $\left.T_{3}\right)$, respectively. The mixtures were homogenized with Ultra Turrax blender (IKA, Merck, Germany) at $14000 \mathrm{rpm}$, to dissolve added ingredients. All batches were heated to $80^{\circ} \mathrm{C}$ for $15 \mathrm{~min}$ and cooled to $42 \pm 1^{\circ} \mathrm{C}$. Then, all batches were inoculated with $(0.02 \% \mathrm{w} / \mathrm{w})$ yoghurt starter culture and $(0.05 \%$ $\mathrm{w} / \mathrm{w}$ ) probiotic culture of ABT-2 starter culture, disposed into plastic cups (200 ml) and incubated at $42 \pm 1^{\circ} \mathrm{C}$ until complete coagulation. Yoghurt treatments were transferred to cool storage at $4 \pm 1^{\circ} \mathrm{C}$, and kept for 14 days and analysed for their physicochemical, microbiological, rheological and sensory properties when fresh and after 7 and 14 days of storage, respectively. Three replicates of probiotic set yoghurt were made.

\section{Physicochemical properties}

Moisture, crude protein, crude fat, crude fiber, titratable acidity as lactic acid and ash contents were determined according to AOAC (2007), and nitrogen free extract (NFE) content was determined by differences (crude protein, crude fat, crude 
fiber and ash) from 100. The dietary fiber was determined according to the method described by Asp et al. (1983). The minerals (K, Ca, Mg, Na, Fe and $\mathrm{Zn}$ ) were determined according to the AOAC (2007). Ca, Mg, Fe and Mn procedures using a Perkin Elmer Atomic Absorption spectrophotometer (Model 2380, Japan), while K and Na were determined by coring flame photometer (Model 410, Japan), and the water holding capacity (WHC) as described by Arslan \& Ozel (2012). The pH was determined using glass electrode $\mathrm{pH}$ meter (Persica model pH 900, Switzerland). Triplicate measures were taken for each sample.

\section{Determination of total phenolic content and antioxidant activity}

One gram sample of defatted DSP was mixed with $10 \mathrm{ml}$ of $80 \%$ methanol and stirred at room temperature for $24 \mathrm{~h}$ and filtered. The total phenolic content (as \% gallic acid) was determined in the filtered by Folin-Ciocalteu reagent according to the method of Lim et al. (2006), while the antioxidant activity was determined by DPPH as described by Brand-Williams et al. (1995) and expressed as percentage inhibition of the DPPH radical.

\section{Rheological properties}

The texture properties of yoghurt were measured at $20^{\circ} \mathrm{C}$ using a texture analyzer (TA1000, Lab Pro (FTC TMS-Pro, USA). A two-bite penetration test was performed and operated at a crosshead speed $1 \mathrm{~mm} / \mathrm{sec}$ and penetration distance of $10 \mathrm{~mm} / \mathrm{sec}$. Hardness, adhesiveness, springiness, cohesiveness, gumminess and chewiness were evaluated by the method described by Bourne (1978).

\section{Microbiological properties}

The total bacterial count was determined according to Marshal (1992). For enumeration of $S$. thermophilus, diluted samples were plated on M17 agar (Oxoid Ltd) and incubated at $37^{\circ} \mathrm{C}$ for $48-72 \mathrm{~h}$ under aerobic conditions (Rybka \& Kailasaphaty1996). L. bulgaricus was determined using MRS-agar (Rybka and Kailasaphaty 1996). L. acidophilus counts were determined using MRS-sorbitol agar while $B$. bifidum was performed on MRS-NNLP medium according to (Dave \& Shah 1998). The plates of $L$. acidophilus cultures and B. bifidum, were anaerobically (Anerocult A system; Merck, Darmstadt, Germany) incubated at $37^{\circ} \mathrm{C}$ for $72 \pm 1 \mathrm{~h}$.

The coliform bacteria, mould \& yeast counts were enumerated according to standard methods for examination of dairy products (Marth, 1998) using the violet red bile agar (VRBA) and acidified potato dextrose agar (PDA), respectively. The results were expressed as log number of colony forming units per $\mathrm{g}(\mathrm{cfu} / \mathrm{g})$. 


\section{Sensory evaluation}

Sensory evaluation of yoghurt samples was carried out by 10 panelists including staff members Faculty of Agriculture El-Shatby, Alexandria University. The sensory attributes tested were taste (45 points), body \& texture (35 points) appearance $\&$ colour (10 points), odour (10 points) and the overall acceptability as described by Ranadheera et al. (2012).

\section{Statistical analysis}

All data were expressed as mean values \pm SD. Statistical analysis was performed using one way analysis of variance (ANOVA) followed by Duncan's Multiple Range Test with $\mathrm{P} \geq 0.05$ being considered statistically significant using SAS software program (SAS, 2004).

\section{RESULTS AND DISCUSSION}

\section{Physicochemical and microbiological properties of defatted DSP}

Table (1) presents the proximate composition of DSP. DSP contained $6.80 \%$ moisture, $6.20 \%$ protein, $0.07 \%$ crude fat and $1.14 \%$ ash. The data showed that DSP had high percentages of crude fiber $(15.12 \%)$. The results obtained in the present study for DSP are in a general agreement with those of Hamada et al. (2002).

The results also showed that, the DSP composed of $75 \%$ neutral detergent fiber (NDF); $57.5 \%$ acid detergent fiber (ADF) and $10.5 \%$ hemicellulose. The ADF is very high, which may indicate the presence of substantial amounts of lignin and perhaps resistant starch in DSP. Almana \& Mahmaud, (1994) evaluated date pits as an alternative source of dietary fiber in comparison with wheat bran, and suggested that they may provide a valuable contribution to dietary fiber intakes. Therefore, DSP were examined because they may have an extractable high value-added components in functional foods.

The data given in Table (1) indicated that DSP had higher total phenolic content $(70.72 \mathrm{mg} / 100 \mathrm{~g})$ and antioxidant activity (45.44\%). The results obtained in the present study are agreement with those reported by Al-Farsi et al. (2007).

The DSP contained several important minerals. The results indicated that the DSP contented the high level of potassium (605 mg/100g) then followed by $\mathrm{Ca}, \mathrm{Mg}$, $\mathrm{Na}$ and $\mathrm{Fe}(289,67,34.8$ and $7.7 \mathrm{mg} / 100 \mathrm{~g})$, respectively. The level of $\mathrm{Zn}$ was considerably low $(1.2 \mathrm{mg} / 100 \mathrm{~g})$. Generally, DSP may be considered as a good source of $\mathrm{K}, \mathrm{Ca}, \mathrm{Mg}$ and $\mathrm{Fe}$. The results obtained in the present study are in a good agreement with those reported by Abdel-Nabey (1999).

From the data in Table (1), it could be observed that the DSP had the highest water holding capacity $(4.34 \mathrm{~g} / \mathrm{g})$. This may be attributed to the high fiber content of 
the DSP. This result agreed with Garcia-Perez et al. (2005) who found that the high fiber content of date palm pits led to high water holding capacity.

In addition, the total bacterial count was $110 \mathrm{cfu} / \mathrm{g}$, while, mould and yeast counts were not detected. The low moisture content permitted better conservation of DSP and inhibited the development of bacteria.

Table 1. physicochemical and microbiological properties of DSP

\begin{tabular}{|l|l|}
\hline Component & Value* \\
\hline Proximate composition (\%) & $6.80 \pm 0.41$ \\
Moisture & $6.20 \pm 0.22$ \\
Crude protein & $15.12 \pm 0.32$ \\
Crude fiber & $0.07 \pm 0.23$ \\
Crude fat & $1.14 \pm 0.35$ \\
Ash & $77.47 \pm 0.49$ \\
Nitrogen free extract (NFE)** & \\
Dietary fiber (\%) & $63.0 \pm 0.49$ \\
NDF & $52.5 \pm 0.34$ \\
ADF & $10.5 \pm 0.05$ \\
Hemicellulose (NDF- ADF) & \\
Bioactive compounds & 70.72 \\
Total phenolic compounds (mg/100g)*** & 45.44 \\
Antioxidant activity (\%) & \\
Minerals (mg/100g) & \\
Calcium (Ca) & $289 \pm 0.74$ \\
Potassium (K) & $605 \pm 0.88$ \\
Sodium (Na) & $34.8 \pm 0.37$ \\
Magnesium (Mg) & $67 \pm 0.42$ \\
Iron (Fe) & $7.7 \pm 0.22$ \\
(Zinc) Zn & $1.2 \pm 0.08$ \\
Water Holding Capacity (WHC) & $4.34 \pm 0.07$ \\
pH & $6.35 \pm 0.08$ \\
Microbiological analysis & \\
Total bacterial counts (cfu/g) & $110 \pm 17$ \\
Yeast and mould counts & $\mathrm{ND}$ \\
\hline
\end{tabular}

NDF: neutral detergent fiber, ADF: acid detergent fiber, ND: Not Detected

$*$ Mean of three replicates \pm SD ${ }^{* *}$ Calculated by difference $* * *$ Gallic acid equivalent

\section{Physicochemical properties of probiotic set yoghurt}

\section{Titratable acidity:}

The titratable acidity of probiotic set yoghurt (Figure 1) decreased with increasing DSP concentrations. This may be due to the pH of DSP (6.35), also high absorption of water by DSP and the water becomes unavailable for starter cultures. Which, results in reducing activity of starter cultures (Tamime \& Robinson, 1999) and lactic acid production. The highest titratable acidity content was found in sample $\mathrm{C}$ (control) in the range of $0.972-1.091 \%$, and the lowest values were found in samples $\mathrm{T}_{3}$ in the range of $0.918-0.994 \%$. In general, the titratable acidity of all samples increased during storage period, which could be due to the presence of the three 
bacterial strains of ABT-2 starter culture and a commercial classic yoghurt starter. This can be explained by further metabolic activity of starter cultures during storage. The lowest value of titratable acidity was found in fresh sample, but the highest value was found on $14^{\text {th }}$ day of storage for the control sample and the other samples containing the different concentration of DSP (Figure 1).



Fig. 1. Titratable acidity of probiotic set yoghurt during the storage period

\section{Water-holding capacity (WHC):}

Figure (2) illustrates the WHC of probiotic set yoghurt prepared using different concentrations of DSP. The plain yoghurt (C) exhibited low value of WHC as compared to the probiotic set yoghurt samples treated with various concentrations of DSP. Figure (2) shows that there was an increase in the WHC of samples with increasing of DSP concentrations. This could be explained by the availability of fiber from DSP, which has high WHC (Garcia-Perez et al. 2005). In general, storage period affected WHC. The values of WHC obtained in fresh sample were lower than those found after 7 and 14 days of refrigerated storage period. Guler-Akin \& Akin (2007) obtained similar results they found that the addition of prebiotics as a waterstructuring agents, act as a thickeners and can form complexes (H-bridge formation) with the protein aggregates in the yoghurt.

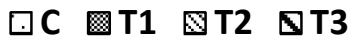

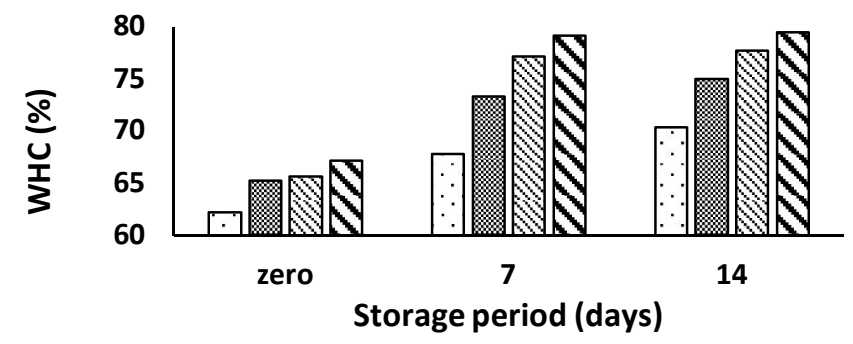

Fig. 2. WHC values of probiotic set yoghurt during the storage period. 


\section{Rheological properties of probiotic set yoghurt}

The effects of DSP and storage period on rheological properties of probiotic set yoghurt during storage period are given in Figure 3 ( $a, b, c$, d, e and f). The following parameter were evaluated:

\section{Hardness}

Hardness values were shown in Figure (3.a). Adding DSP and increasing their concentrations resulted in decreased of hardness values in comparison to plain yoghurt (C). During storage period the hardness of yoghurt increased till the end of storage period. Similar results were obtained during storage of probiotic Torba yoghurt (Kasenkas, 2010). The increase of hardness could be due to the reduction of $\mathrm{pH}$ during storage, causing the gel to contract and consequently increased gel firmness (Coggins et al. 2010). The hardness of probiotic set yoghurt was found to be affected by its composition and $\mathrm{pH}$.

\section{Adhesiveness}

Probiotic set yoghurt with different concentrations of DSP had the lowest adhesiveness values comparing with the plain yoghurt (Figure 3.b). Additionally, the probiotic set yoghurt with $0.5 \%$ DSP $\left(\mathrm{T}_{3}\right)$ had lower adhesiveness values than that containing low concentration of DSP $\left(T_{1}\right)$. During storage period the adhesiveness of probiotic set yoghurt increased till the end of storage period. Probably, the high content of DSP reflected the low adhesiveness values for those samples and produced yoghurt with soft. The results revealed an inverse relationship between adhesiveness and hardness.

\section{Cohesiveness:}

The data in figure (3.c) showed that cohesiveness values of yoghurts were affected by DSP. Adding DSP and increasing their concentrations resulted in a decrement of cohesiveness in comparison to the plain yoghurt (C). Addition of DSP increased the cohesiveness values in probiotic set yoghurt with $0.5 \% \mathrm{DSP}\left(\mathrm{T}_{3}\right)$ after 7 days, and then decreased with increasing the storage period. Addition of DSP may be responsible for the observed differences in the cohesiveness.

\section{Springiness:}

Addition of DSP influenced the springiness values of probiotic set yoghurt. Adding DSP and increasing their concentrations resulted in an increment of springiness in comparison to the plain yoghurt (C). The data in figure (3.d) showed that the springiness of probiotic set yoghurt with $0.5 \% \operatorname{DSP}\left(T_{3}\right)$ gained a high value than plain yoghurt (C). The data in figure (3.d) showed that the springiness decreased during storage except. 


\section{Gumminess}

The data in figure (3.e) showed that the gumminess tended to increase during 7 days in all treatment, and then decreased during storage period. The lowest gumminess values were observed after 7 days with $0.5 \%$ DSP $\left(T_{3}\right)$.

\section{Chewiness}

Chewiness showed similar trends as in case of gumminess. The data in figure (3.f) showed that the chewiness of probiotic set yoghurt increased during 7 days of storage for all treatments then decreased tell the end of storage period.
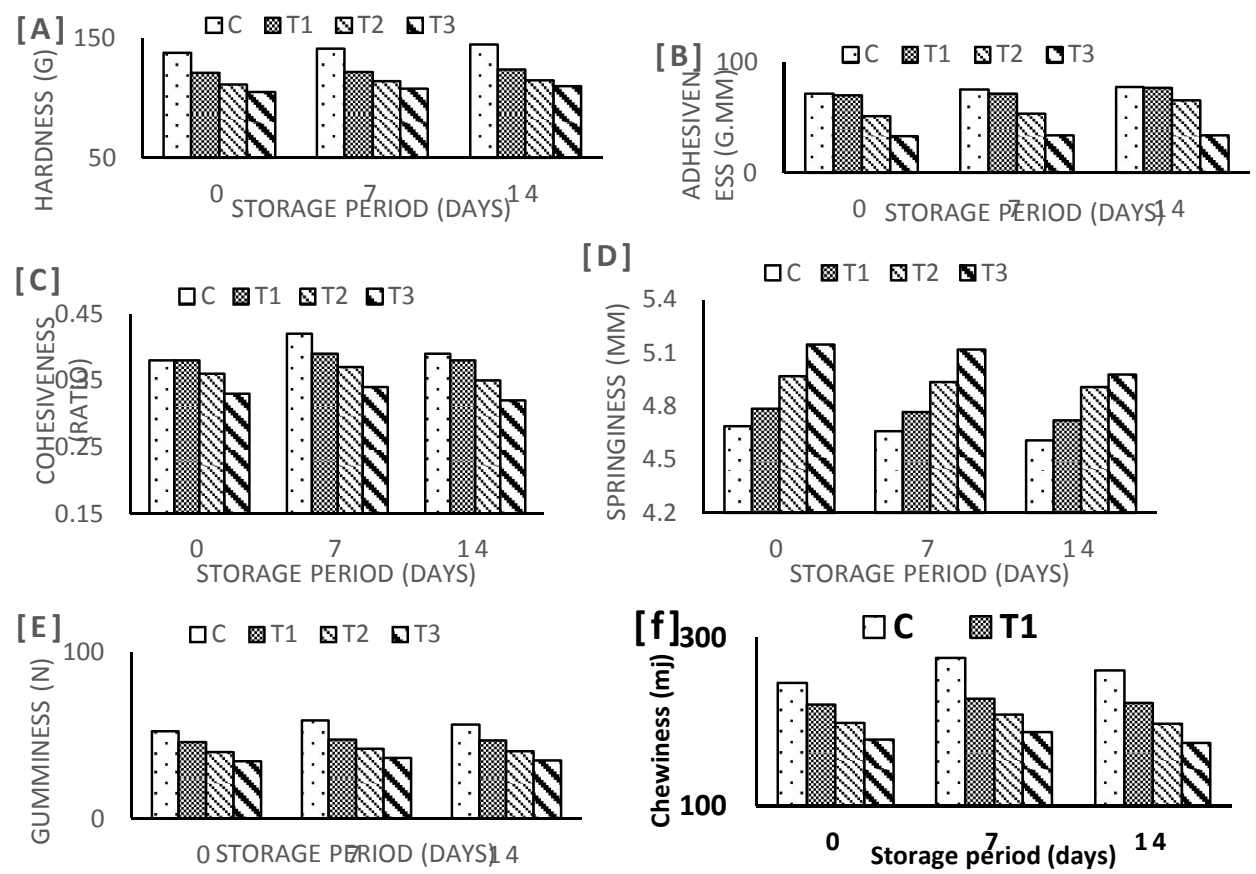

Fig. 3. Rheological properties of probiotic set yoghurt during the storage period ( $a$, Hardness; $b$, adhesiveness; c, Cohesiveness; d, Springiness; e, Gumminess; f, Chewiness)

\section{Microbiological properties of probiotic set yoghurt Total bacterial count}

Total bacterial count (log $\mathrm{cfu} / \mathrm{g}$ ) of probiotic set yoghurt containing DSP are presented in Figure (4.a). The obtained results indicated that during storage period, the total bacterial count gradually decreased until the end of the storage period. These results may be due to the low storage temperature. Total bacterial counts of probiotic set yoghurt containing DSP in all concentrations were higher than that of the control sample at the end of the storage period. From these results, it might be said that the highest degree of DSP added to the probiotic set yoghurt caused a positive effect on the total bacterial count during the storage period. . Similarly, Dave \& Shah (1998) reported that the addition of prebiotics to ABT yoghurts stimulated the growth of probiotic bacteria. 


\section{L. bulgaricus and S. thermophiles}

The viability of $L$. bulgaricus and $\mathrm{S}$. thermophiles of probiotic set yoghurt containing DSP during storage period are presented in Figure (4.b and 4.c). The viable cell counts of $L$. bulgaricus (Figure 4.b) decreased from 8.99-9.59 log $\mathrm{cfu} / \mathrm{g}$ at the beginning of storage to $8.72-9.32 \log \mathrm{cfu} / \mathrm{g}$ at the end of the storage period. Also the results obtained for the probiotic set yoghurt (Figure 4.C) showed that S. thermophilus was present at the level of 8.52-9.39 log cfu/g during storage. It was observed that counts of L. bulgaricus and S. thermophiles strains decreased during storage. The highest mean of $L$. bulgaricus and $S$. thermophiles count was found in $T_{3}$, while the lowest mean value was obtained in $C$ and $T_{1}$. Similar results were also reported by Dave \& Shah, (1998). From these results, it might be noted that the highest concentration of DSP added to the probiotic set yoghurt caused a positive effect on the $L$. bulgaricus and $S$. thermophiles count during storage. Moreover, several studies have shown that yoghurt bacteria (S. thermophilus and L. bulgaricus) survive well in yoghurt throughout the shelf life (Pescuma et al. 2010).

\section{L. acidophilus LA-5 and Bifidobacterium BB-12}

The changes of viable counts of $L$. acidophilus LA-5 and B. bifidum BB-12 in the probiotic set yoghurt containing DSP during storage period are shown in Figure (4.d and 4.e). The amount of L. acidophilus LA-5 and B. bifidum BB-12 were 6.88-8.18 and 6.8-8.25 log cfu/g during storage period. The highest mean count was found in sample $T_{3}$, and the lowest mean count was found in sample $C$ (control). It was observed that a higher addition of DSP leads to an increase in the viable counts of these bacteria. The number of viable of $L$. acidophilus LA-5 and B. bifidum BB-12 decreased slightly during the storage period, but remained at sufficient levels ( $>6$ log $\mathrm{cfu} / \mathrm{g}$ ) for up to 14 days. Bakirci \& Kavaz (2008) mentioned that the total viable counts of S. thermophilus, L. acidophilus and B. bifidum of banana yoghurt decreased slightly during the refrigerated storage, but remained at sufficient levels ( $>6$ log $\mathrm{cfu} / \mathrm{g}$ ) for up to 14 days. According to the variance analysis, there were no statistically significant $(P>0.05)$ differences in the viable counts of $L$. acidophilus $L A-5$ and $B$. bifidum BB-12 during days of storage.

\section{Coliform, mould \& yeast counts}

The coliform, mould \& yeast counts were not detected in all the probiotic set yoghurt samples containing DSP during storage period in both fresh and at the end of the storage period. This is due to good hygienic conditions during preparation and storage. These results are in agreement with those of Salman et al. (2012). 

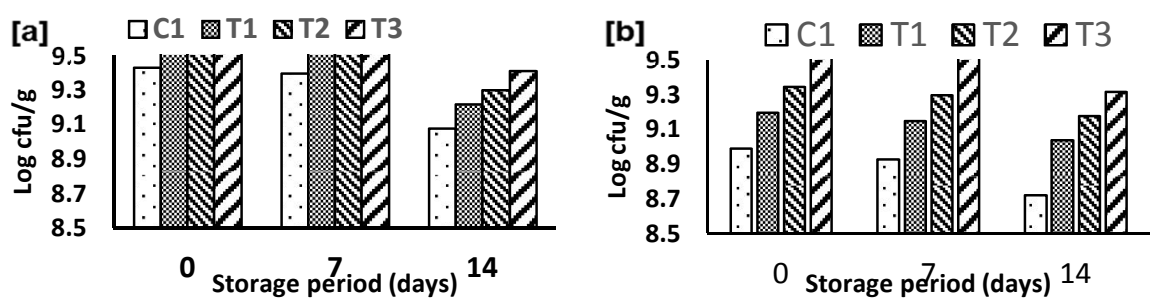

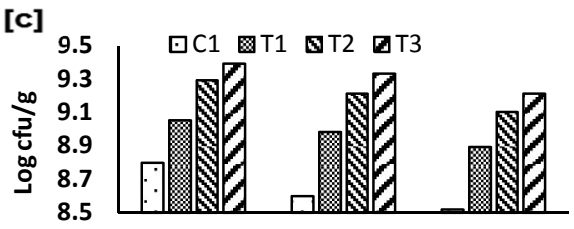

0 Storage period (days) 14

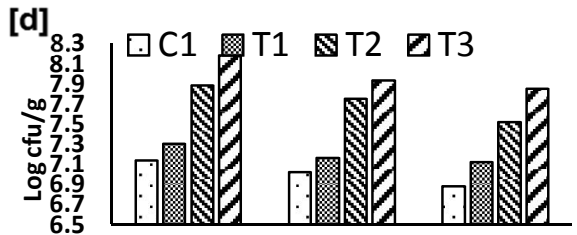

0 Storage period (days) 14

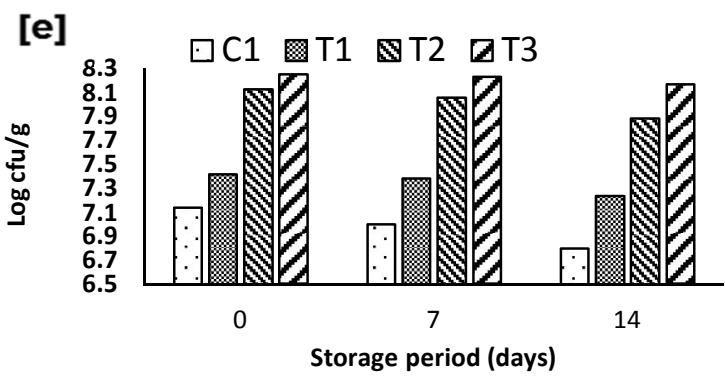

Fig. 4. Microbiological properties of probiotic set yoghurt during the storage period (a, Total bacterial; b, L. bulgaricus; c, S. thermophilus; d, L. acidophilus and e, B. bifidum count

\section{Sensory properties}

The mean scores for the sensory characteristics of probiotic set yoghurt containing different concentrations of DSP are presented in Table 2. Generally, all samples were acceptable. Addition of DSP had a positive effect $(P<0.05)$ in the scores for taste, body \& texture and overall acceptability of the set yoghurt samples.

However, no significant effect $(P>0.05)$ was observed on the appearance \& colour and odour scores by the addition of DSP. The storage period did not affect all the sensory parameters tested (Table 2). As noted from Table (2), the highest body \& texture scores were obtained in sample T3 (0.5\% DSP). 
Table 2. Sensory properties of probiotic set yoghurt during the storage period

\begin{tabular}{|c|c|c|c|}
\hline \multirow[t]{2}{*}{ Treatments } & \multicolumn{3}{|c|}{ Storage period (days) } \\
\hline & Fresh & 7 & 14 \\
\hline \multicolumn{4}{|c|}{ Taste (45) } \\
\hline C & $44.40 \pm 0.64^{\mathrm{A} \mathrm{a}}$ & $44.60 \pm 0.73^{\mathrm{A} \mathrm{a}}$ & $44.30 \pm 0.62^{\mathrm{A} \mathrm{a}}$ \\
\hline $\mathrm{T}_{1}$ & $43.60 \pm 1.07 \mathrm{AB}$ a & $43.80 \pm 1.17 \mathrm{AB}$ a & $43.90 \pm 0.43 \mathrm{AB}$ a \\
\hline $\mathrm{T}_{2}$ & $43.10 \pm 1.22{ }^{A B}$ a & $43.60 \pm 1.17$ АВ a & $42.90 \pm 0.77 \mathrm{AB}$ a \\
\hline $\mathrm{T}_{3}$ & $43.00 \pm 1.13 \mathrm{AB}$ a & $43.40 \pm 1.32 \mathrm{AB} \mathrm{a}$ & $43.70 \pm 1.15 \mathrm{AB}$ a \\
\hline \multicolumn{4}{|c|}{ Body and texture (35) } \\
\hline $\mathrm{C}$ & $28.10 \pm 1.56^{\mathrm{Ca}}$ & $27.10 \pm 1.32^{\mathrm{C} a b}$ & $26.10 \pm 0.71^{c b c}$ \\
\hline $\mathrm{T}_{1}$ & $30.00 \pm 1.42^{\mathrm{B} \mathrm{a}}$ & $28.80 \pm 1.11^{\mathrm{B} \text { ab }}$ & $28.10 \pm 1.71^{\mathrm{B} b c}$ \\
\hline $\mathrm{T}_{2}$ & $30.60 \pm 2.11^{\mathrm{AB} a}$ & $29.80 \pm 2.45^{\mathrm{A} \mathrm{a}}$ & $29.80 \pm 1.11^{\mathrm{B} \mathrm{b}}$ \\
\hline $\mathrm{T}_{3}$ & $31.00 \pm 1.45^{\mathrm{A} \mathrm{a}}$ & $30.60 \pm 0.63^{\mathrm{A} a b}$ & $30.00 \pm 2.43^{\mathrm{Ab}}$ \\
\hline \multicolumn{4}{|c|}{ Appearance and colour(10) } \\
\hline C & $8.30 \pm 0.33 \mathrm{~A} \mathrm{a}$ & $8.30 \pm 1.11^{\mathrm{A} \mathrm{a}}$ & $8.20 \pm 1.23 \mathrm{~A} \mathrm{a}$ \\
\hline $\mathrm{T}_{1}$ & $8.20 \pm 1.16^{\mathrm{A} \mathrm{a}}$ & $8.20 \pm 1.11^{\mathrm{A} \mathrm{a}}$ & $8.15 \pm 1.43 \mathrm{~A} \mathrm{a}$ \\
\hline $\mathrm{T}_{2}$ & $8.20 \pm 1.22^{\mathrm{A} \mathrm{a}}$ & $8.20 \pm 0.71^{\mathrm{Aa}}$ & $8.15 \pm 1.13^{\mathrm{A} \mathrm{a}}$ \\
\hline$T_{3}$ & $8.15 \pm 1.56^{\mathrm{Aa}}$ & $8.10 \pm 1.00^{\mathrm{A} \mathrm{a}}$ & $8.05 \pm 1.32^{\mathrm{Aa}}$ \\
\hline \multicolumn{4}{|c|}{ Odour (10) } \\
\hline C & $9.10 \pm 1.11^{\mathrm{A} \mathrm{a}}$ & $8.90 \pm 1.23^{\mathrm{Aa}}$ & $8.90 \pm 1.21^{\mathrm{Aa}}$ \\
\hline $\mathrm{T}_{1}$ & $9.00 \pm 0.12^{\mathrm{Aa}}$ & $8.80 \pm 1.12^{\mathrm{Aa}}$ & $8.75 \pm 1.11^{\mathrm{A} \mathrm{a}}$ \\
\hline $\mathrm{T}_{2}$ & $9.00 \pm 0.76$ A a & $8.80 \pm 0.76 \mathrm{Aa}$ & $8.70 \pm 1.04 \mathrm{~A} \mathrm{a}$ \\
\hline $\mathrm{T}_{3}$ & $9.00 \pm 1.40 \mathrm{Aa}$ & $8.70 \pm 1.12^{\mathrm{Aa}}$ & $8.65 \pm 1.34 \mathrm{Aa}$ \\
\hline \multicolumn{4}{|c|}{ overall acceptability (100) } \\
\hline C & $89.90 \pm 2.10^{\mathrm{B} \mathrm{a}}$ & $88.90 \pm 3.55^{\mathrm{Ca}}$ & $87.50 \pm 2.17^{\mathrm{Cb}}$ \\
\hline $\mathrm{T}_{1}$ & $90.80 \pm 3.10^{\mathrm{B} \mathrm{a}}$ & $89.60 \pm 2.21^{\mathrm{BC} \mathrm{a}}$ & $88.90 \pm 2.50^{\mathrm{B} a b}$ \\
\hline $\mathrm{T}_{2}$ & $90.90 \pm 2.231^{\mathrm{Aa}}$ & $90.40 \pm 0.45^{\mathrm{A} a b}$ & $89.55 \pm 2.24^{\mathrm{A} \mathrm{bc}}$ \\
\hline$T_{3}$ & $91.15 \pm 2.00^{\mathrm{Aa}}$ & $90.80 \pm 2.32^{\mathrm{B} \mathrm{a}}$ & $90.40 \pm 2.16^{\mathrm{BC} \mathrm{b}}$ \\
\hline
\end{tabular}

C: control without DSP, $\mathrm{T}_{1}: 0.1 \% \mathrm{DSP}, \mathrm{T}_{2}: 0.3 \% \mathrm{DSP}$ and $\mathrm{T}_{3}: 0.5 \%$ DSP

$(A-E)$ Different capital superscripts in the same column indicate significant differences $(P<0.05) ;(a-C)$ Different lowercase superscripts in the same row indicate significant differences $(P<0.05)$.

\section{CONCLUSION}

Prebiotic stabilizer (DSP) has many benefits when added to yoghurt. These benefits include: prebiotic effects on probiotics, nutraceutical health benefits, texture improvement, nutritional enrichment, reduced syneresis and extended the shelf-life of yoghurt. Prebiotic stabilizer (DSP) is added to probiotic set yoghurt in order to support the viability of probiotic strains to make these products, synbiotics, beneficial for consumers' health. Analysis of prebiotic stabilizer (DSP) suggested that DSP can be used in foods as an inexpensive source of dietary fiber and other functional components, e.g. resistant starch. Prebiotic stabilizer (DSP) exhibited a positive relationship with yoghurt quality parameters. 


\section{REFERENCES}

1. Abdel-Nabey. 1999. Chemical composition and oil characteristics of date pits of six Egyptian cultivars. Alexandria Journal Agriculture Research 44(1): 127

2. Al-Farsi, M., Alasalvar, C., Al-Abid, M., AlShoaily, K., Al-Amry, M., and Al-Rawahy, F. 2007. Compositional and functional characteristics of dates, syrups, and their by-products. Food Chemistry 104 (3), 943-947.

3. Almana, HA, Mahmoud, R. M. 1994. Palm date seed as an alternative source of dietary fiber in Saudi bread. Ecology of Food and Nutrition 32(3):261-270

4. AOAC. 2007. Official Methods of Analysis of the AOAC. International $18^{\text {th }}$ Ed. Gaithersburg, Maryland, USA.

5. Arslan, S. and Ozel, S. 2012. Some properties of stirred yoghurt made with processed grape seed powder, carrot juice or a mixture of grape seed powder and carrot juice. Milchwissenschaft 67 (3):281-285.

6. Asp, N, G., Joansson, C, G., Hallmer, H., and Siljestrom. M. 1983. Rapid enzymatic assay of insoluble and soluble dietary fiber. Journal Agriculture Food Chemistry 31:476-482.

7. Bakirci, I and A. Kavaz. 2008. An investigation of some properties of banana yogurts made with commercial ABT-2 starter culture during storage. International Journal Dairy Technology 61(3): 270-276.

8. Bourne, M. C. 1978. Texture profile analysis. Food Technology. 32: 62-72.

9. Brand-Williams, W., Cuvelier, ME., Berset, C. 1995. Use of a free radical method to evaluate antioxidant activity. Lebenson Wiss Technology 28:25-30

10. Coggins, P. C., Rowe, D.E., Wilson, J.C. and Kumari, S. 2010. Storage and temperature effects on appearance and textural characteristics of conventional milk yoghurt. Journal of Sensory Studies 25:549-576.

11. Dave, R.I., Shah, N.P. 1998. Ingredient supplementation effects on viability of probiotic bacteria in yoghurt. Journal of Dairy Science 81: 2804-2816.

12. Garcia-Perez, F J., Lario, Y., Fernandez-Lopez, J., Sayas, E., Perez-Alverez, J A. and Sendra, E. 2005. Effect of orange fiber addition on yoghurt color during fermentation and cold storage. Industrial Applications 30 457-463.

13. Guler-Akin, M B. and Akin, M S. 2007. Effects of cysteine and different incubation temperatures on the microflora, chemical composition and sensory characteristics of bio-yoghurt made from goat's milk. Food Chemistry 788-793.

14. Hamada, JS. Hashim, IB., Shari, AF. 2002. Preliminary analysis and potential uses of date pits in foods. Food Chemistry 76: 135-137. 
15. Ha, E. and Zemel. M. B. 2003. Functional properties of whey, whey components, and essential amino acids: mechanisms underlying health benefits for active people. Journal Nutrition Biochemistry 14:251-258

16. Kasenkas, H. 2010. Effect of using different probiotic cultures on properties of Torba (strained) yoghurt. Mljekarstvo 60 (1), 19-29.

17. Lim, Y. Y., Lim, T. T. and Jing, J. 2006. Antioxidant properties of guava fruit: comparison with some local fruits, Sunway Academic Journal 3: 9-20.

18. Marshal, R. T. 1992. Standard Methods for Examination of Dairy Products 16th ed. American Public Health Association Washington, D.C.

19. Marth, E.H. 1998. Extended shelf life refrigerated foods microbiological quality and safety. A sientific status summary by the institute of food technologists' expert panel on food safety and nutrition. Chicago, ш. Food Technology 52(2): 57-62.

20. Pescuma, M., Hébert, E.M. Mozzi, F. and De Valdez, G.F. 2010. Functional fermented whey-based beverage using lactic acid bacteria. Int. Journal Food Microbiology 141(1-2): 73-81.

21. Ranadheera, S., Evans, C.A., Adams, M.C., Baines, S.K. 2012. Probiotic viability and physico- chemical and sensory properties of plain and stirred fruit yogurts made from goat's milk. . Food Chemistry 135: 1411-1418.

22. Rybka, S. and Kailasaphaty, K. 1996. Media for enumeration of yogurt bacteria. International Dairy Journal 6:839-850.

23. Salman, K.H., Mansour, A. I. A., Tammam, A. A. and El-Gazzar, F. E. 2012. Utilization of egg-shell powder as a calcium fortifier in stirred dibis probiotic yoghurt. Assiut Journal Agriculture Science 43:1.

24. SAS. 2004. SAS Institute Inc. SAS/ETS ${ }^{\circledR} 9.1$ User' SAS Institute Inc. 2004. SAS/ETS $\Re 9.1$ User's Guide. Cary, NC.

25. Tamime, A.Y. and Robinson, R.K. 1999. Yoghurt: Science and technology. 2nd Edition, pp 1-118. Washington DC: CRC Press. 


\section{إنتاج يوغورت حيوي مدعم بمسحوق \\ نوي البلح كبريبيوتك ومثبت طبيعي}

\section{وداد محمد الخولى}

$$
\text { قسم بحوث الالبان - معهر بحوث تكنولوجيا الأغذية - مركز البحوث الزراعية }
$$

هدفت هذه الدراسة إلى تقييم استخدام مسحوق نوي البلح (DSP) كبريبيوتك ومثبت طبيعي في

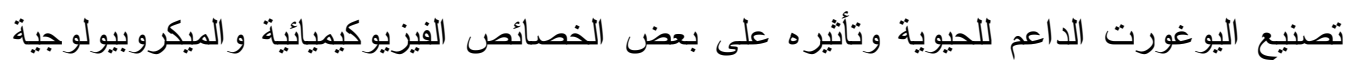

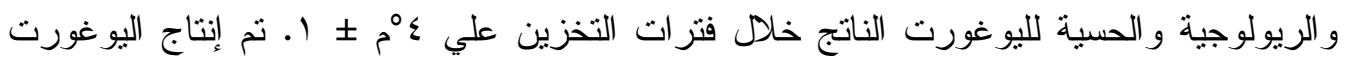

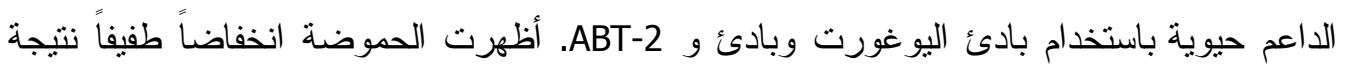



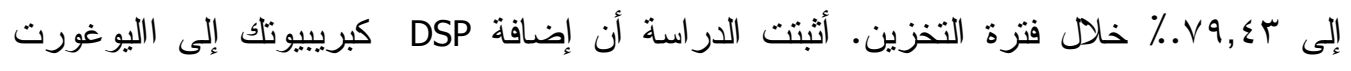

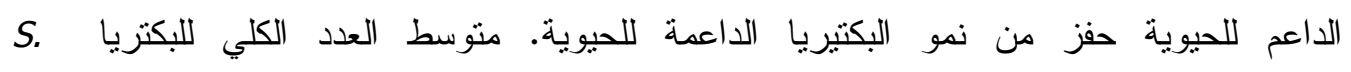
(thermophilus, L. acidophilus and B. bifidum BB-12) ولكنها بقيت عند مستويات كافية (6 log cfu/g) خلال ع ا يوما من التخزين. و أخير الوحظ عدم

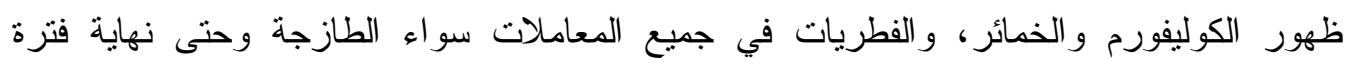

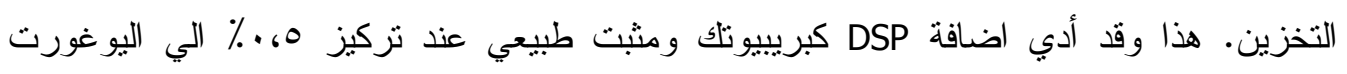
الداعم للحيوية الي تحسين الصفات الحسية و الريولوجية مقارنة باليوغورت المعامل بالتركيزات الأخرى. 